\title{
Humanly Gods or Godly Humans: Representation and Anthropomorphism of Mythical Characters in Amish Tripathi's Shiva Trilogy
}

\author{
Aritra Basu \\ M.Phil. Research Scholar \\ University of Delhi \\ Delhi, India \\ basuaritra16@gmail.com
}

\begin{abstract}
This paper attempts to analyse the representation of mythical characters in the three novels by Amish Tripathi, namely The immortals of Meluha, The secret of the Nagas and The oath of the Vayuputras. The protagonist is a human being, Shiva, whose bildungsroman through the trilogy transforms him into a God, but without actually changing any of his physical attributes. Thus, at the level of anthropomorphism, this method of representation sheds light on the humane aspect of the divinity. From a perspective of feminist understanding of disability, the character of Kali would be studied, as an initial outcast to an important character in the last two books. Thus, this paper would conclude that Tripathi attempts at a vision of inclusivity, by his clever techniques of the representation of the disabled and the divine alike.
\end{abstract}

Keywords: Anthropomorphism, Disability, Myth, History, Marginalisation. 
The larger-than-life representation of characters with a divine prospect has been the signature move of Indian epics, legends, Vedas and Upanishads. While some of them were born out of a union between a God and a human, others were avatars or versions of Gods themselves. There are several versions of the same narrative, told from various perspectives, which somewhat correspond to Linda Hutcheon's definition of historiographic metafiction, which is "still committed to telling a long and involving story, full of believable characters which can be enjoyed by the readers in the manner of nineteenth century realism." (Nicol 99) Thus, representation is problematized at its very source, and that is what is exploited by Amish Tripathi in his bestselling Shiva trilogy.

Extending the argument presented in the essay entitled 'Giving voice to the marginalised: A study of Amish Tripathi's The immortals of Meluha', this paper would try to shed some light on the representation of the marginalised characters as opposed to the representation of the divine entity, Shiva. One important thing to note in this context, namely, that the disabled characters of Kali and Ganesh are introduced to us only in the second book of the trilogy. Though the first book has ample mention of the Nagas or the Vikarmas (the polluted), the main characters from the former category take some time to find proper representation. Thus, the marginalised voices increase as the trilogy traverses towards fruition, in terms of the character of the Vikarma, Sati, in the first book, Kali and Ganesh in the second book and all of them together in the third book, occupying the centre stage.

Amish Tripathi in his bestseller Shiva trilogy explores this grey area and tries to break the divine jargon, slicing it into pieces small enough for undereducated or culturally unaware readers with little or no knowledge of mythology proper to understand. The light which was cast by Roland Barthes in his book Mythologies, highlighting the importance of society and the then contemporary social values in the creation and sustenance of myths, also helps a great deal to understand the stance that Amish takes. For the avid reader, who has the basic knowledge 
of Indian mythology from the two very basic epics of the land The Ramayana and The Mahabharata, this series of books starts off as mildly disturbing, as it voyages on lands never dwelt in basic ancient Indian mythology. However, as the narrative progresses, interest slowly seeps in as the reader finally understands that what Amish is trying to depict is not the history, but an alternative version of history. He wants to challenge the historiographic authenticity of said myths and goes ahead to interpret and mould them in his own indigenous way to create a new narrative with identifiable characters.

The very introductory page of the Shiva trilogy reads, "What if Lord Shiva was not a figment of rich imagination, but a person of flesh and blood? Like you and me. A man who rose to become godlike because of his karma. This is the premise of the Shiva trilogy, which interprets the rich mythological heritage of ancient India, blending fiction with historical fact." Thus, from the very outset we are introduced to a figure who is a human being, before anything else. However, within the first chapter, the representation of Shiva gains an added advantage over that of the other characters. Several myths and legends from the epics, Vedas and Upanishads have been interpreted and modified in their own ways. For instance, Shiva's famous name Neelkanth has been given a different pretext and context, notwithstanding the story of the churning of the oceans as described in Indian mythology. In the book, in the very first chapter, a particular liquid was offered to the Guna tribe once they reached the city of Srinagar by Ayurvati, the chief of medicine. As a result, the entire tribe suffers from high fever and sweating, except Shiva, whose throat turned blue as a result of that incident. Finding that an age old prophecy has come true, the Meluhans declare Shiva as their saviour against the Chandravanshis who have teamed up with the deformed Nagas to take possession of whatever little water was left of the river Saraswati.

The ancient Indian culture of untouchability also finds mention in the very first book of the trilogy. Shiva instantly feels attracted to Sati, but learns that she is a Vikarma, a kind of 
people considered untouchable. The fact that she cannot be loved or touched, let alone married was so deeply ingrained in her psyche that even when Shiva made advances towards her, he was greeted with great belligerence. However, Shiva steps up to the occasion and declares himself as the Neelkanth and promises to eradicate all such kind of prejudices. It is in this book we see that in ancient India, gender discrimination was not such big an issue as it is today, as both man and woman train to dance and fight, without being judged for either. The most significant part of appropriation of myths comes towards the end of the novel, when the Chandravans his get furious at seeing the Neelkantha and claim that their race was the one who were supposed to be delivered by the Neelkanth and not their rivals the Suryavanshis. This part of the narrative highlights how people generally misinterpret myths and legends according to their own ways. One is reminded of Joan Kelly Gadol's essay 'Did Women have a Renaissance', where by extension, the entire existence of the Renaissance has been questioned, because as Kelly argues, it was, like a lot of other things, an eighteenth century construct by Europe in general and England in particular to establish its superiority over its colonies.

The first book of the Shiva Trilogy, The Immortals of Meluha, starts off with an adventure in the land of Meluha, and the subsequent departure of Shiva and his friends from Tibet to Meluha, the near perfect empire created many centuries ago by Lord Ram where he is meant to fulfil his destiny. Starting from an ordinary human being with distinctive qualities of leadership, a strong personality, this series charts the growth of Shiva from a human being to a deity. Thus, deification becomes paramount of importance in this narrative. We see his followers chant "Om namah Shivay", something which is essentially associated with gods. As the story progresses, he gains the title of Mahadev or the supreme divine. During the time of battle, the inspirational leader in him awakens and he shouts out to his troops "Har Har Mahadev", meaning that every single soldier of the army is Mahadev and can fight just as ferociously and fearlessly as Mahadev himself, reminding the readers of communism. 
The thin line of difference between history, myth, legend and fiction is completely blurred by Amish, as he anthropomorphises the character of Lord Shiva to begin with and then goes on to do the same to other known figures of Indian mythology, like Goddess Kali, Durga, Lord Ganesh and many others. He brings home controversy from staunch believers when he portrays Lord Ganesh as a physically deformed child who had been abandoned by his parents and Goddess Kali as the not-so-presentable sister of Durga, or as she is called here, Sati, who in her time was abandoned by her parents. Devdutt Pattanaik from The Tribune commented that "the writer takes us on a sinister journey with the characters, who frequently sound as if they are one of us only". The characters are essentially humane, they have flaws, emotions and urges. However, in this bildungsroman of Shiva the protagonist, Amish also intertwines the subtext of contemporarisation. Standing in the twenty-first century, it is getting more and more difficult for teachers, scholars and critics alike to get students interested in Indian myths, legends and stories as the Postcolonial hangover, instead of waning away, spread its giant legs into every nook and corner of our third world academia. Amish thus chooses the road of fiction to tell a story which is popular, but to make it more palatable he tactically brings in essentially modernist concepts like the question of identity, existentialism, alienation and many more things. He also does not forget to include clichés from the classics like destiny, love and very obviously, conflict.

In the second book of the Shiva Trilogy, The Secret of the Nagas, Amish continues the story of Shiva, but along with destabilising popular myths about Gods and Goddesses, Amish also shows most of them as human beings, thus highlighting the humanitarian aspect of the deities. Lord Ganesh is shown to be a child born with deformities and thus an outcast. Thus, Amish brings in aspects such as societal 'otherisation' within a mythical narrative. Besides providing historians with a different perspective on events from the myths, it also shows the universality and versatility of them, interpreting and moulding them into his very own 
narratives. In a recent review of the book written for a blog in the WordPress website, it is said: "There is some nuanced wisdom in this book. Wisdom that Amish could have captured in beautiful ways, but he couldn't. This is where the flaw lies. Given that this book is based on age-old stories that have come to us because of their indestructible nature, one would hope to have bursts of takeaways. Alas, his writing fails him here. Nonetheless, I loved the portion where Shiva's uncle explains to him how he is not responsible for other people's karma, only his karma. There are umpteen events where the book says that evil is just another side of a coin. In fact, the way Shiva uncovers the truth of why people do what they do explains why we should never judge a person."

The occasional adherence to the grand narratives on and of mythologies in India finds the best example in this book when the son of Shiva and Sati, Kartick, is born. According to almost all the popular and known mythologies, Kartick was known to be the better looking and better 'deserving' son of the two. Here too, before the arrival of Ganesh, he is shown to be born, though it is revealed later that Ganesh is, in fact, older than him by quite some margin. The alter ego of Sati, in the form of her twin sister Kali, also makes her first appearance in this book. Their father, Daksha, abandoned her at childbirth and then abandoned sati's son Ganesh at childbirth too, because both of them were deformed to a great degree. This reveals to the readers the fact that the father, in spite of being a powerful man, chose to abide by the norms and rules laid down by society, and it took someone as powerful, independent and almost literally 'divine' like Shiva to actually try and break those norms to establish equality in the truest sense of the term, at least in the society in which he lives. The second half of the book shows a true change in the ladder of hierarchy as Shiva gets Daksha to admit that he had murdered Sati's first husband and had abandoned the two children at different points of time. Knowing this, he orders Daksha to leave them and go back to Meluha while he finally reconciles with his full family after much turmoil and complications. What is significant here 
is the fact that Shiva belonging to a rank of military as well as sovereign inferiority than Daksha actually orders the latter to do something, which is in turn obeyed. This reveals to us the fact that even the deluded king has accepted the fact that the divine lord is above all the rules and chains of this earth, as he submits to the former's power, assertion and righteousness.

While the Meluhans' attitude towards the disabled reflected an adherence to the religious model of disability, where they thought that any kind of deformity was a result of past sins; the attitude of Daksha was more akin to the social model, wherein he tried to outcast the disabled child Kali, and Sati's disabled child, Ganesh. These disabled people, known as the Nagas, formed a separate group of outcasts who were later brought back to the mainstream by Shiva. Thus, Tripathi, surely but subtly, brings forth issues about disability and its representation at a time when it was still to gain currency in India. The moment the secret about the identity of Kali is revealed, "Then listen, oh exalted Princess. I am your twin sister, Kali. The one whom your two-faced father abandoned" is immediately reminiscent of Susan Wendell's essay. 'Towards a feminist theory of disability'. Where Wendell says,

"This theory should be feminist, because more than half of disabled people are women and approximately $16 \%$ of women are disabled, and because feminist thinkers have raised the most radical issues about cultural attitudes to the body. Some of the same attitudes about the body which contribute to women's oppression generally also contribute to the social and psychological disablement of people who have physical disabilities. In addition, feminists are grappling with issues that disabled people also face in a different context: Whether to stress sameness or difference in relation to the dominant group and in relation to each other; whether to place great value on independence from the help of other people, as the dominant culture does, or to question a value-system which distrusts and de-values dependence on other people and vulnerability in general; whether to take full integration into male dominated/able- 
bodied society as the goal, seeking equal power with men/able-bodied people in that society, or whether to preserve some degree of separate culture, in which the abilities, knowledge and values of women/the dis-abled are specifically honoured and developed." (Wendell 3)

Thus, this book promises to build on this proposition of a feminist theory of disability, by giving Kali the centre-stage for this book and the next, and by proving that she deserves equality irrespective of her gender or her physical form.

The last book of the trilogy, The Oath of the Vayuputras, completes the story and ends with a universal message that weapons of mass destruction (the Bramhastra here) are always deplorable and best if avoided. The book starts off with an issue which is very relevant in the modern day discourse of resources and their consequent misuse, in the form of misuse of the water of river Saraswati to create somras for the people of Meluha. Brahaspati points this out to Shiva and the latter responses like any sensible man from twenty first century would, which makes the text even more appealing. This blend of the two frames of time is brought about almost perfectly by Amish, which makes his books an ideal choice for such a detailed analysis of mythology and their contemporarisation It shows that how love can blind even someone who has, over due course of time, been transformed into nothing less than a God. Indian mythology showcases the Gods as flawless in most of the cases, but this series tries to show that there is a flip side to that coin, through alternative representation. Like the tragic hero, Shiva also falls prey to hubris, and thus the representation of the divine being completes a full circle as he comes back to the realm of the humans again, after making a grave mistake. 


\section{Works Cited}

Amish Tripathi; The immortals of Meluha; Chennai: Westland ltd; 2010.

--The Secret of the Nagas; Chennai: Westland ltd; 2011.

--The oath of the Vayuputras; Chennai: Westland ltd; 2013.

Barthes, Roland. Mythologies; translated by Annette Lavers; New York: The Noonday Press; 1972, pp. 127-130.

Pattanaik, Devdutt, Tribune Newspaper Interview, Chandigarh, Tribune Daily, 19.09.2010.

Nicol, Bran. ed. The Cambridge companion to Postmodern fictions; New York: Cambridge University Press; 2009, p. 99.

Tripathi, Amish. The immortals of Meluha; Chennai: Westland ltd; 2010, p. 3.

Wendell, Susan. "Towards a feminist theory of disability"; Hypatia, Volume 4, Number 2; 1989, pp. 104-124.

\section{Web Sources}

WordPress; Review of the secret of the Nagas; web; Date of access: $10^{\text {th }}$ June 2019.

https://www.google.com/amp/s/bookhad.wordpress.com/2013/03/19/the-secret-of-the-nagas-

review/amp/ 